\title{
Calculation of sheep and beef economic weightings for the seasonal dry matter production trait for use in a forage-cultivar selection decision-support tool
}

\author{
Cameron I. LUDEMANN \\ Cameron Ludemann Consulting, Arnhem, The Netherlands \\ cameronludemann@gmail.com
}

\begin{abstract}
Development of an independent forage-cultivar selection decision-support tool (DST) could transfer substantial benefits to sheep and beef (S\&B) farmers. This study took a first step toward development of a S\&B DST by describing and assessing one method of calculating S\&B forage trait economic weightings. The 'change in livestock production' economic weighting method was applied to the Otago/Southland Breeding Finishing Farm Class in this study. The trait economic weightings for the seasonal dry matter (DM) production trait were applied to cultivar performance trial data using the DairyNZ Forage Value Index (FVI) framework. Analysis indicated the rankings of perennial ryegrass cultivars using the DST method varied from those calculated using the DairyNZ FVI when using the same seasonal DM production data. It was concluded the change in livestock production method is an option for calculating the economic value of traits for evaluation of perennial ryegrass cultivars that are more applicable to S\&B farmers. However, this method should be applied to a wider range of S\&B Farm Classes before a decision is made as to its suitability for the New Zealand S\&B industry.
\end{abstract}

Keywords: FVI, Lolium perenne, plant breeding, yield

\section{Introduction}

The New Zealand dairy industry has had an independent forage evaluation system (DairyNZ Forage Value Index-FVI) since 2011 (Chapman et al. 2017). This functionality allows the dairy industry to provide farmers with an independent evaluation of cultivars of perennial ryegrass for selection decisions and provide plant breeders a signal to guide their breeding objectives. The value of the DairyNZ FVI has been estimated at about $\$ 160$ million each year (DairyNZ 2017). Development of a similar foragecultivar selection decision-support tool (DST) could transfer substantial benefits to sheep and beef $(\mathrm{S} \& \mathrm{~B})$ farmers given the high dependence the New Zealand $\mathrm{S} \& \mathrm{~B}$ industry has on home-grown feed.

The seasonal dry matter (DM) production trait was introduced into the DairyNZ FVI in 2011 and, since then, a framework ('DairyNZ framework') has been refined to include new forage traits of metabolisable energy content (Ludemann et al. 2018) and persistence (Ludemann \& Chapman 2019). Key components of the performance of cultivars of perennial ryegrass are converted into units farmers are familiar with and that can be applied across traits. This process involves calculating the change in farm operating profit for the unit change in the trait to convert cultivar performance into a common unit (dollars) that is applicable among different traits. Various methods of calculating the economic values of forage traits have been described (McEvoy et al. 2011; Smith \& Fennessy 2011; Ludemann \& Smith 2016; O'Donovan et al. 2016; Chapman et al. 2017; Leddin et al. 2018; Ludemann \& Chapman 2019). Each method has advantages and disadvantages.

Plant breeders and those who want to compare the overall performance of pasture plant cultivars should consider the marginal value of every extra kilogram of DM produced (Lewis et al. 2020). This approach may use the value of feed substitutes - 'replacement cost' method- as approximations for the economic value of pasture DM (Hardin \& Johnson 1955; Lewis et al. 2013; Ludemann et al. 2013). While simple to calculate, the replacement cost method (using barley prices) may accurately reflect neither inter-seasonal variations in value of pasture to farmers nor the greater opportunity cost of pasture if it is consumed by livestock and converted into products (Ludemann \& Smith 2016). In contrast, Smith and Fennessy (2011) estimated the relative weightings for forage traits through surveys of experts using discrete choice experiments. This involved asking experts which of two options they preferred when some of the options had known economic values, so relative weightings of different traits could be estimated. An advantage of this method is that it may elucidate relative weightings of traits that are difficult to measure the economic value for, however the relative rankings may differ between certain groups of people surveyed in certain traits (Smith \& Fennessy 2011).

An alternative non-survey method of calculating the value of seasonal DM is to model the expected value of the change in livestock production (the 'change in livestock production' method) (Ludemann \& Smith 
2016). The 'change in livestock production' method requires more data and a better understanding of the classes of livestock that represent the region under examination than the replacement cost method. The 'change in livestock production' method may provide a more realistic assessment of the inter-annual variability in value of traits without the need for either expensive farm experiments or detailed farm systems models, which provide results that are specific only to one situation. Achieving a balance between the complexity of the system modelled and adequacy of information for decision making is required when developing models (Behrendt et al. 2013). The change in livestock production method was highlighted by Ludemann and Smith (2016) as an alternative to detailed farm system models, on farm experiments and replacement cost methods. The change in livestock production method can provide a good balance between the cost of estimation and its applicability to a wide range of farms, whilst still accounting for the inter-seasonal variability of the economic value of DM production. The purpose of this study is to assess the change in livestock production method in the calculation of perennial ryegrass economic values for seasonal DM production in an approach similar to that developed for the DairyNZ FVI. The method was applied to the Otago/ Southland breeding finishing Farm Class (Beef + Lamb NZ 2019) to provide context. The hypothesis tested was whether rankings of cultivars using the S\&B DST would vary from those calculated using the DairyNZ FVI using the same seasonal DM performance data.

\section{Materials and Methods}

\section{Calculation of the sheep and beef forage-cultivar} decision-support tool (DST)

Equation 1 was used to calculate the DST of perennial ryegrass cultivars (i):

$$
D S T^{i}=\sum\left(P V D M_{a}^{i x} \times E W D M_{a}^{i j}\right) \quad \text { [Equation 1], }
$$

where the $P V D M_{a}^{i x}$ were the same performance values for the seasonal DM production trait as those used in the DairyNZ FVI when it included only this trait (Chapman et al. 2017). The difference between the 2017 DairyNZ FVI equation and DST (Equation 1) was the use of trait economic weights $(E W)$ for the seasonal DM production trait $\left(E W D M_{a}^{i j}\right)$ for the DST as opposed to the use of trait economic values $(E V)$ for the 2017 DairyNZ FVI. The $E W D M_{a}^{i j}$ equation for the DST still included economic value for DM $\left(E V D M_{a}^{i j}\right)$ as shown in Equation 2. However, the economic values were multiplied by industry weighting factors (IWF) $\left(I W F D M_{a}^{i j}\right)$ for a given season ' $a$ ' and region ' $j$ ' for each cultivar ' $i$ ':
$E W D M_{a}^{i j}=E V D M_{a}^{i j} \times I W F D M_{a}^{i j} \quad$ [Equation 2].

At a high level, the EVDM ${ }_{\mathrm{a}}{ }^{\mathrm{ij}}$ (like the DairyNZ FVI) was calculated as:

$$
E V D M_{a}^{i j}=\frac{\text { Change in farm operating profit }}{\text { Unit change in forage trait }} \text { [Equation 3]. }
$$

In Equation 3, the change in DM production is presented in units of $\mathrm{kg} \mathrm{DM}$ grown and the change in farm operating profit is given in units of NZ dollars. Further explanation of how Equation 3 was calculated for a S\&B context is included in the next two sections.

\section{Change in livestock production economic value method}

The change in livestock production economic value $\left.(\triangle \operatorname{ProdEVDM})_{t}\right)$ for period $t$ was calculated based on Equation 4:

$$
\triangle P \operatorname{ProdEVDM} M_{t}=\frac{D M M E}{(E / U)} \times M P \quad \text { [Equation 4]. }
$$

where $D M M E$ is the pasture DM metabolisable energy content (in MJME/kg DM), $E$ is the energy required for the class of livestock to produce the product (in MJME/unit product calculated using standard CSIRO (2007) equations), $U$ is the utilisation of pasture DM by the class of livestock (expressed as a proportion of DM available), and $M P$ is the market price of the product produced by that class of livestock. This equation follows principles similar to those employed by Ludemann and Smith (2016). However, instead of applying the change in livestock production economic value method to changes in carcase weight alone as was the case for Ludemann and Smith (2016) - a generalised equation was developed to include other products such as live weight and body condition score gains. Parameters used to calculate $\triangle P$ rodEVDM for each class of livestock are included in Table 1 for sheep and Table 2 for cattle enterprises.

Many breeding animals are not sold (such as non-cull, breeding ewes and cows) during the year as shown in Tables $1 \& 2$. Therefore, the direct benefits of additional DM cannot be calculated based only on changes in carcase weight or liveweight sold. To overcome this limitation, the value in livestock production from noncull ewes and breeding cows was based on changes in body condition score. The effect of changes in body condition score on reproductive performance was shown to be variable and probably have a curvilinear relationship by Kenyon et al. (2014). This situation complicates calculation of the economic value of pasture DM based on changes in body condition score. Therefore, the opportunity cost of feed for otherwise gaining body condition was used to estimate the value 
Table 1 Parameters used for each class of sheep livestock in the calculation of the economic value of dry matter (DM) using the 'change in livestock production' method where ES means early-season, MS means mid-season and LS means lateseason lambs.

\begin{tabular}{|c|c|c|c|c|c|c|c|c|c|c|}
\hline \multirow{3}{*}{ 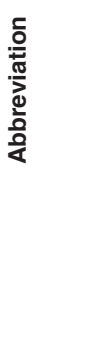 } & \multirow[t]{2}{*}{ Parameter } & \multirow[t]{2}{*}{ Units } & \multicolumn{8}{|c|}{ Class of livestock } \\
\hline & & & $\begin{array}{l}\text { Weaned } \\
\text { lamb }^{1}\end{array}$ & $\begin{array}{c}\text { ES } \\
\text { prime } \\
\text { lamb }\end{array}$ & $\begin{array}{l}\text { MS } \\
\text { prime } \\
\text { lamb }\end{array}$ & $\begin{array}{l}\text { LS } \\
\text { prime } \\
\text { lamb }\end{array}$ & $\begin{array}{c}\text { Replace- } \\
\text { ment } \\
\text { ewe }\end{array}$ & $\begin{array}{l}\text { Prime } \\
\text { hogget }\end{array}$ & $\begin{array}{l}\text { Cull } \\
\text { ewes }\end{array}$ & $\begin{array}{l}\text { Mixed } \\
\text { age } \\
\text { ewe } \\
\text { lamb }\end{array}$ \\
\hline & $\begin{array}{l}\text { Product } \\
\text { (name and } \\
\text { units) }\end{array}$ & $\begin{array}{l}\text { Name } \\
\text { and } \\
\text { units }\end{array}$ & $\begin{array}{c}\text { Live } \\
\text { weight } \\
\text { (kg) }\end{array}$ & $\begin{array}{c}\text { Carcase } \\
\text { weight } \\
\text { (kg) }\end{array}$ & $\begin{array}{c}\text { Carcase } \\
\text { weight } \\
\text { (kg) }\end{array}$ & $\begin{array}{c}\text { Carcase } \\
\text { weight } \\
\text { (kg) }\end{array}$ & $\begin{array}{c}\text { Live } \\
\text { weight } \\
\text { (kg) }\end{array}$ & $\begin{array}{l}\text { Carcase } \\
\text { weight } \\
\text { (kg) }\end{array}$ & $\begin{array}{c}\text { Carcase } \\
\text { weight } \\
(\mathbf{k g})\end{array}$ & $\begin{array}{l}1 \text { body } \\
\text { condition } \\
\text { score } \\
\text { (BCS) }\end{array}$ \\
\hline- & $\begin{array}{l}\text { Baseline units } \\
\text { of product }\end{array}$ & Units & 28.0 & 17.3 & 17.3 & 17.3 & 65.5 & 19.3 & 26.2 & 3.0 \\
\hline$E$ & $\begin{array}{l}\text { Energy requirement } \\
\text { per unit of product }\end{array}$ & $\begin{array}{l}\text { MJME/unit } \\
\text { product }\end{array}$ & 35.4 & 101.7 & 105.1 & 112.1 & 73.0 & 145.4 & 246.3 & 427.8 \\
\hline MP & $\begin{array}{l}\text { Market price } \\
\text { of product }^{6}\end{array}$ & $\$ /$ unit product & 2.98 & 6.79 & 6.46 & 6.26 & 2.70 & 6.50 & 3.40 & 15.82 \\
\hline$U$ & $\begin{array}{l}\text { Utilisation of } \\
\text { pasture DM }\end{array}$ & $\begin{array}{l}\text { Proportion of } \\
\text { offered feed } \\
\text { consumed }\end{array}$ & 0.60 & 0.60 & 0.60 & 0.60 & 0.65 & 0.65 & 0.70 & 0.70 \\
\hline DMME & $\begin{array}{c}\text { Annual average } \\
\text { pasture energy } \\
\text { content }^{7}\end{array}$ & MJME/kg DM & 10.60 & 10.60 & 10.60 & 10.60 & 10.60 & 10.60 & 10.60 & 10.60 \\
\hline
\end{tabular}

${ }^{1}$ Value of weaned lamb based on weaned lamb sale price off-ewe.

2 These lambs received ES lamb prices related to the months of August and end of September, with $5 \%$ of lambs sold in this season.

3 These lambs received MS lamb prices related to the months of October through to the end of January, with $35 \%$ of lambs sold in this season.

${ }^{4}$ These lambs received LS lamb prices related to the months of February through to the end of July, with $60 \%$ of lambs sold in this season.

${ }^{5}$ Used CSIRO (2007) equations.

${ }^{6}$ Market prices of products came from the Beef +Lamb NZ Economics Team and were 5-year rolling average values (inflation adjusted) except for the market price of liveweight of replacement lambs and the market price of change in body condition score in ewes. The cost of the these were calculated as the total energy required per unit product multiplied by the barley replacement cost of feed per unit energy utilised.

${ }^{7}$ Based on data from sheep and beef farms from Upsdell et al. (2017).

of a change in body condition score. The cost of gaining condition was based on the equivalent energy cost of feed barley $($ Feed $\$$ ). The Feed $\$$ (in $\$ /$ MJME utilised) was calculated as:

Feed $\$_{t}=\frac{M P F_{t}+A F E_{t}}{1000 \text { gg_tonne } \times F P r o p_{D M} \times F P r o p_{U} \times F E_{t}}$

[Equation 5].

As shown in Table 3, the $M P F_{t}$ is the real 5-year rolling average market price of feed at point $t$ in time, $A F E_{t}$ is the real 5-year rolling average additional feed expenses (such as repairs and maintenance and transport costs of feeding equipment or additional labour to feed it out) (in dollars per tonne fresh weight for the purchased feed), the $1000 \mathrm{~kg}$ _tonne represents the conversion factor for tonnes to kilograms, FProp $_{D M}$ is the barley feed DM as a proportion of fresh weight, FProp $_{U}$ is the proportion of purchased barley feed DM utilised by livestock, and $F E_{t}$ is the barley feed energy content in megajoules of metabolisable energy per kilogram of DM.

\section{Industry weighting factors}

Industry weighting factors are used in animal geneticselection indices to weight the economic value of a trait by a factor that reflects the region being modelled (Byrne et al. 2012). Similarly for the present study, IWF were included in the EW calculation to weight the EV (calculated for each class of livestock using the 'change in livestock production' method) in order to reflect the Farm Class under investigation. To illustrate the rationale for IWF, consider the following scenario. If there were an increase in pasture production of $100 \mathrm{~kg}$ DM across a sheep and beef farm that had improved cultivars in every paddock, then not all the extra DM may be consumed by one class of livestock. In a dairy farm system with fewer classes of livestock, it may mean use of IWF is of less concern when estimating the economic value of forage traits (therefore the EW is equal to the EV). However, for a sheep and beef farm system with more classes of livestock we must account for the economic value of extra DM grown and consumed by those classes of livestock.

The IWF were, therefore, calculated as the 
Table 2 Parameters used for each class of cattle livestock in the calculation of the economic value of dry matter (DM) using the 'change in livestock production' method.

\begin{tabular}{|c|c|c|c|c|c|c|c|c|c|}
\hline \multirow{3}{*}{ 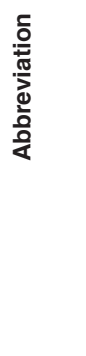 } & \multirow[t]{2}{*}{ Parameter } & \multirow[t]{2}{*}{ Units } & \multicolumn{7}{|c|}{ Class of livestock } \\
\hline & & & $\begin{array}{l}\text { Weaner } \\
\text { calf } \\
\text { sold } \\
\text { store }\end{array}$ & $\begin{array}{c}\text { Replace- } \\
\text { ment } \\
\text { heifers } \\
\text { change in } \\
\text { live weight }\end{array}$ & $\begin{array}{c}\text { Store } \\
\text { cattle } \\
\text { sold } \\
1-1.5 \\
\text { years }\end{array}$ & $\begin{array}{l}\text { Prime } \\
\text { cattle-P } \\
\text { grade- } \\
\text { heifer/ } \\
\text { steer }\end{array}$ & $\begin{array}{l}\text { Prime } \\
\text { cattle-M } \\
\text { grade- } \\
\text { bull }\end{array}$ & $\begin{array}{l}\text { Mature cow } \\
\text { body } \\
\text { condition } \\
\text { score } \\
\text { (BCS) }\end{array}$ & $\begin{array}{l}\text { Cull } \\
\text { cow } \\
\text { sold } \\
\text { prime }\end{array}$ \\
\hline & $\begin{array}{c}\text { Product } \\
\text { (name and } \\
\text { units) }\end{array}$ & $\begin{array}{c}\text { Name } \\
\text { and } \\
\text { units }\end{array}$ & $\begin{array}{c}\text { Live } \\
\text { weight } \\
\text { (kg) }\end{array}$ & $\begin{array}{c}\text { Live } \\
\text { weight } \\
\text { (kg) }\end{array}$ & $\begin{array}{c}\text { Carcase } \\
\text { weight } \\
\text { (kg) }\end{array}$ & $\begin{array}{c}\text { Carcase } \\
\text { weight } \\
\text { (kg) }\end{array}$ & $\begin{array}{c}\text { Live } \\
\text { weight } \\
\text { (kg) }\end{array}$ & BCS & $\begin{array}{c}\text { Carcase } \\
\text { weight } \\
\text { (kg) }\end{array}$ \\
\hline- & Baseline units of product & Units & 210.0 & 310.0 & 310.0 & 194.4 & 194.4 & 5.0 & 276.6 \\
\hline$E$ & $\begin{array}{l}\text { Energy requirement } \\
\text { per unit of product }{ }^{1}\end{array}$ & $\begin{array}{l}\text { MJME/unit } \\
\text { product }\end{array}$ & 42.7 & 49.6 & 64.1 & 122.8 & 122.0 & 1748.6 & 130.9 \\
\hline MP & $\begin{array}{l}\text { Market price } \\
\text { of product }{ }^{2}\end{array}$ & \$/unit product & 3.49 & 1.83 & 3.49 & 5.49 & 5.35 & 64.68 & 4.11 \\
\hline U & $\begin{array}{c}\text { Utilisation of pasture } \\
\text { DM }\end{array}$ & $\begin{array}{c}\text { Proportion of } \\
\text { offered feed } \\
\text { consumed }\end{array}$ & 0.60 & 0.70 & 0.70 & 0.70 & 0.70 & 0.70 & 0.70 \\
\hline DMME & $\begin{array}{c}\text { Annual mean } \\
\text { pasture energy } \\
\text { content }^{3}\end{array}$ & MJME/kg DM & 10.60 & 10.60 & 10.60 & 10.60 & 10.60 & 10.60 & 10.60 \\
\hline
\end{tabular}

1 Used CSIRO (2007) equations.

2 Market prices of products came from the Beef +Lamb NZ Economics Team using 5-year rolling average values (inflation adjusted) except for the market price of liveweight of replacement heifers and the change in body condition score in cows. The cost of these were calculated as the total energy required per unit product multiplied by the barley replacement cost of feed per unit energy utilised.

3 Based on data from sheep and beef farms from Upsdell et al. (2017).

Table 3 Assumptions used in the calculation of Feed\$t for the barley replacement cost method.

\begin{tabular}{|c|c|c|c|c|}
\hline Abbreviation & Description & Units & Value & Reference \\
\hline MPF $_{t}$ & $\begin{array}{l}\text { 5-year (Sept } 2014 \text { to Aug 2019) } \\
\text { mean real market price of barley feed for t years. }\end{array}$ & \$/tonne & 386 & $\begin{array}{l}\text { DairyNZ } \\
\text { economics team }\end{array}$ \\
\hline $\mathrm{AFE}_{\mathrm{t}}$ & $\begin{array}{l}\text { Additional barley feeding expenses } \\
\text { (on top of market price) for } t \text { years }{ }^{1} \text {. }\end{array}$ & $\$ /$ tonne present day value & 25 & \\
\hline FProp $_{\mathrm{DM}}$ & Barley dry matter as a proportion of fresh weight. & $\mathrm{kg} \mathrm{DM} / \mathrm{kg}$ fresh weight & 0.90 & Rayner (2007) \\
\hline FProp $_{u}$ & Proportion of barley utilised by livestock. & $\mathrm{kg}$ consumed $/ \mathrm{kg}$ offered & 0.95 & Rayner (2007) \\
\hline $\mathrm{FE}_{\mathrm{t}}$ & Mean barley metabolisable energy content. & MJME/kg DM & 13 & Rayner (2007) \\
\hline Feed $\$$ t & $\begin{array}{l}\text { Mean replacement cost of feed } \\
\text { per unit of energy utilised. }\end{array}$ & \$/MJME utilised & 0.04 & \\
\hline PProp $_{u}$ & Proportion of pasture utilised by livestock. & $\mathrm{kg}$ consumed $/ \mathrm{kg}$ offered & 0.70 & Byrne et al. (2012) \\
\hline
\end{tabular}

${ }^{1}$ Includes costs such as transporting, handling and feeding out barley.

proportions of total pasture DM energy consumed in each month and season by each class of livestock. The breeding ram/bull and minor classes of livestock did not have EW calculated because in total they made up less than $2 \%$ of pasture DM energy consumed and would, therefore, have an insignificant effect on overall trait EW. The IWF were calculated using CSIRO (2007) livestock energy requirement equations and the mean number of livestock and livestock productivity factors that represented the region of interest. For this study, data from the 'Otago/Southland Finishing Breeding Farm Class' were used (Beef +Lamb NZ 2019). While in this study, the IWF were calculated based on proportion of extra dry matter consumed by each class of livestock, there is flexibility to apply more weighting on certain classes of livestock if deemed appropriate. 
For instance, in late spring, an IWF of 1 could be applied to the lamb classes of livestock if the decision maker deemed it appropriate for their farm system.

\section{Statistical analysis}

Perennial ryegrass cultivars eligible for the 2020 DairyNZ FVI lists were included in analysis of the DST calculation. The absolute DST and DST rankings of cultivars were compared with the absolute FVI and FVI rankings of the 35 cultivars in the 2020 DairyNZ FVI for the Lower South Island. Comparisons were made using correlation coefficients of all cultivars, and mean values for three functional groups were calculated. The functional groups included mid-heading diploids, lateheading diploids and tetraploids (Wims et al. 2017). Three scenarios for the change in livestock production DST were simulated to test sensitivity of cultivar rankings to key assumptions. Scenario 1 assumed the body condition score component of the calculation for economic value of seasonal DM was unchanged. In Scenario 2, the opportunity cost of otherwise gaining body condition score in breeding ewes and cattle was set to zero (as opposed to the \$0.04/MJME utilised values used in Scenario 1) because pasture DM in late spring was in much greater supply than livestock demand. Scenario 3 was the same as Scenario 2 except that a 30-day delay in ewe mating date (from the 20 April date used for Scenarios 1 and 2) was made. This change was included to assess how applicable DST cultivar rankings at a regional level may be to famers with different lambing dates to those assumed in the model.

\section{Results}

The IWF for the sheep (Table 4) and cattle (Table 5) classes of livestock indicated that the 'breeding' classes of livestock such as replacement-ewe lambs, mixed-age ewes and breeding cows consumed most of the energy

Table 4 Industry weighting factors* for the sheep livestock classes in the calculation of the sheep and beef forage-cultivar decision-support tool for Scenario 1.

\begin{tabular}{lccccccccc}
\hline Season & \multicolumn{10}{c}{ Class of livestock } \\
\cline { 2 - 10 } & $\begin{array}{c}\text { Weaned } \\
\text { lambs }\end{array}$ & $\begin{array}{c}\text { Prime lamb } \\
\text { (Early-season) }\end{array}$ & $\begin{array}{c}\text { Prime lamb } \\
\text { (Mid-season) }\end{array}$ & $\begin{array}{c}\text { Prime lamb } \\
\text { (Late-season) }\end{array}$ & $\begin{array}{c}\text { Replacement- } \\
\text { ewe lamb }\end{array}$ & $\begin{array}{c}\text { Prime } \\
\text { hogget }\end{array}$ & $\begin{array}{c}\text { Cull } \\
\text { ewe }\end{array}$ & $\begin{array}{c}\text { Mixed-age } \\
\text { ewe }\end{array}$ \\
\hline Winter & 0.00 & 0.00 & 0.00 & 0.00 & 0.22 & 0.01 & 0.13 & 0.54 \\
E Spring & 0.26 & 0.00 & 0.00 & 0.00 & 0.17 & 0.00 & 0.09 & 0.35 \\
L Spring & 0.36 & 0.00 & 0.01 & 0.02 & 0.15 & 0.00 & 0.06 & 0.25 \\
Summer & 0.00 & 0.01 & 0.07 & 0.15 & 0.24 & 0.01 & 0.07 & 0.29 \\
Autumn & 0.00 & 0.00 & 0.00 & 0.02 & 0.23 & 0.02 & 0.12 & 0.48 \\
Annual & 0.12 & 0.00 & 0.02 & 0.05 & 0.20 & 0.01 & 0.09 & 0.37 \\
\hline
\end{tabular}

* Industry weighting factors (IWF) do not include breeding rams/bulls and minor classes of livestock in this table, hence annual IWF of sheep and cattle do not sum to 1 .

${ }^{1}$ As defined by Chapman et al. (2017), where $\mathrm{E}=$ Early and L=Late.

Table 5 Industry weighting factors* for the cattle livestock classes in the calculation of the sheep and beef forage-cultivar decision-support tool values for Scenario 1.

\begin{tabular}{lccccccc}
\hline Season & \multicolumn{1}{c}{ Class of livestock } & & & \\
\cline { 2 - 9 } & $\begin{array}{c}\text { Weaner } \\
\text { calves } \\
\text { sold store } \\
\text { live weight }\end{array}$ & $\begin{array}{c}\text { Replacement } \\
\text { heifers } \\
\text { change in } \\
\text { live weight }\end{array}$ & $\begin{array}{c}\text { Store } \\
\text { cattle } \\
\text { sold } \\
\mathbf{1 - 1 . 5} \text { years }\end{array}$ & $\begin{array}{c}\text { Prime } \\
\text { cattle-P } \\
\text { grade- } \\
\text { heifers /steers }\end{array}$ & $\begin{array}{c}\text { Prime } \\
\text { cattle-M } \\
\text { grade- } \\
\text { bulls }\end{array}$ & $\begin{array}{c}\text { Mature } \\
\text { cow body } \\
\text { condition } \\
\text { score }\end{array}$ & $\begin{array}{c}\text { Cull } \\
\text { cows } \\
\text { sold } \\
\text { prime }\end{array}$ \\
\hline Winter & 0.00 & 0.02 & 0.02 & 0.00 & 0.01 & 0.04 & 0.00 \\
E Spring & 0.01 & 0.01 & 0.01 & 0.00 & 0.01 & 0.07 & 0.01 \\
L Spring & 0.02 & 0.01 & 0.01 & 0.00 & 0.01 & 0.08 & 0.01 \\
Summer & 0.03 & 0.01 & 0.01 & 0.00 & 0.01 & 0.08 & 0.01 \\
Autumn & 0.01 & 0.01 & 0.02 & 0.00 & 0.01 & 0.06 & 0.01 \\
Annual & 0.01 & 0.01 & 0.01 & 0.00 & 0.01 & 0.07 & 0.01
\end{tabular}

* Industry weighting factors (IWF) do not include breeding rams/bulls and minor classes of livestock in this table, hence annual IWF of sheep and cattle do not sum to 1 .

1 As defined by Chapman et al. (2017), where E=Early and L=Late. 
throughout the year. For instance, $20 \%$ of total energy consumed was by replacement ewe lambs, and $46 \%$ was consumed by mixed age ewes and cull ewes. In total, lambs sold store or prime consumed $18 \%$ of the energy. Breeding cows consumed the most energy of the cattle class of livestock, with consumption of $7 \%$ of the total energy consumed on the farm.

The trait economic weightings for the seasonal DM production trait (Table 6) varied by calculation method. Of the S\&B calculations, Scenario 3 showed the least inter-seasonal variability with a range of $\$ 0.07 / \mathrm{kg}$ DM grown, compared with $\$ 0.08 / \mathrm{kg}$ DM grown for Scenario 2 and \$0.11/kg DM grown for Scenario 1. All three scenarios assessing changes in production showed less inter-seasonal variation than the 2020 DairyNZ DM economic values, which had a seasonal range of $\$ 0.41 / \mathrm{kg}$ DM grown.

The greatest overall mean DST was calculated for the late-heading diploid cultivars using Scenario 1 (\$273/ha/year) (Table 7). In contrast, the tetraploid functional group had a mean value of $\$ 112 /$ ha/year when calculated using the DairyNZ FVI method giving it the least valuable DST of any method or functional group (Table 7). The functional group that consistently had the greatest DST across methods was the lateheading diploid group followed by the tetraploid group (Table 7).

Regression coefficients of results in Table 8 indicate there were differences in the absolute values, order and star ratings of cultivars among the scenarios and methods tested. The greatest differences were seen between the cultivar star ratings using the DairyNZ FVI method and Scenario 1 using the DST $\left(\mathrm{R}^{2}=0.92\right)$. To put this $\mathrm{R}^{2}$ value into perspective, the DairyNZ FVI scenario had five cultivars in the 5-star rated category of which two of these cultivars were not categorised as 5-star rated using the Scenario 1 DST method. Furthermore, the DairyNZ FVI had nine cultivars in the

Table 6 Seasonal dry matter trait economic weights or economic values using the forage-cultivar decision-support tool (DST) and DairyNZ FVI methods of calculation for the Otago/Southland Breeding Finishing Farm Class.

\begin{tabular}{|c|c|c|c|c|c|}
\hline \multirow{2}{*}{$\begin{array}{l}\text { Season }{ }^{1} \\
\text { (where } \\
\text { E=Early } \\
\text { and } \\
\text { L=Late) }\end{array}$} & \multirow{2}{*}{$\begin{array}{l}\text { Length of } \\
\text { season } \\
\text { (months) }\end{array}$} & \multicolumn{3}{|c|}{$\begin{array}{l}\text { Trait economic weights (in } \$ / \mathrm{kg} \mathrm{DM} \text { grown) } \\
\text { for various calculation methods }\end{array}$} & \multirow{2}{*}{$\begin{array}{c}\text { Trait economic value (\$/kg DM grown) } \\
\text { DairyNZ FVI Lower South Island } \\
\text { for } 2020\end{array}$} \\
\hline & & $\begin{array}{c}\text { DST } \\
\text { change in } \\
\text { livestock } \\
\text { production- } \\
\text { Scenario } 1\end{array}$ & $\begin{array}{c}\text { DST } \\
\text { change in } \\
\text { livestock } \\
\text { production- } \\
\text { Scenario } 2\end{array}$ & $\begin{array}{c}\text { DST } \\
\text { change in } \\
\text { livestock } \\
\text { production- } \\
\text { Scenario } 3\end{array}$ & \\
\hline Winter & 2 & 0.25 & 0.25 & 0.25 & 0.42 \\
\hline E Spring & 2 & 0.33 & 0.33 & 0.28 & 0.48 \\
\hline L Spring & 2 & 0.36 & 0.27 & 0.27 & 0.19 \\
\hline Summer & 3 & 0.29 & 0.29 & 0.32 & 0.07 \\
\hline Autumn & 3 & 0.25 & 0.25 & 0.26 & 0.24 \\
\hline
\end{tabular}

${ }^{1}$ As defined by Chapman et al. (2017)

Table 7 Absolute sheep and beef forage-cultivar decision-support tool (DST) values of different functional groups of perennial ryegrass with three scenarios for calculating trait economic weightings as compared with the 2020 DairyNZ Forage Value Index (where only the seasonal DM production trait performance data were included).

Functional group

Mean absolute value (in \$/ha/year)

\begin{tabular}{|c|c|c|c|c|}
\hline $\begin{array}{l}\text { Number of } \\
\text { cultivars }\end{array}$ & $\begin{array}{l}\text { DST change } \\
\text { in livestock } \\
\text { production- } \\
\text { scenario } 1\end{array}$ & $\begin{array}{c}\text { DST change } \\
\text { in livestock } \\
\text { production- } \\
\text { scenario } 2\end{array}$ & $\begin{array}{c}\text { DST change } \\
\text { in livestock } \\
\text { production- } \\
\text { scenario } 3\end{array}$ & $\begin{array}{c}2020 \text { DairyNZ } \\
\text { FVI for } \\
\text { Lower } \\
\text { South Island }\end{array}$ \\
\hline
\end{tabular}

\begin{tabular}{lccccc}
\hline Mid-heading diploid & 13 & 170 & 162 & 170 & 113 \\
Late-heading diploid & 17 & 273 & 252 & 270 & 136 \\
Tetraploid & 5 & 186 & 177 & 190 & 112 \\
All cultivars & 35 & 222 & 208 & 222 & 124 \\
\hline
\end{tabular}

${ }^{1}$ As defined by Wims et al. (2017). 
Table 8 Regression coefficients of cultivars for the sheep and beef forage-cultivar decision-support tool (DST) under three scenarios compared with the 2020 DairyNZ Forage Value Index (where only the seasonal DM production trait performance data were included)

\begin{tabular}{lcccc}
\hline Cultivar parameter & \multicolumn{3}{c}{ The $\mathbf{R}^{2}$ value for each calculation method ${ }^{1}$} \\
\cline { 2 - 5 } & $\begin{array}{c}\text { DST change in } \\
\text { livestock production- } \\
\text { scenario 1 }\end{array}$ & $\begin{array}{c}\text { DST change in } \\
\text { livestock production- } \\
\text { scenario 2 }\end{array}$ & $\begin{array}{c}\text { DST change in } \\
\text { livestock production- } \\
\text { scenario 3 }\end{array}$ & $\begin{array}{c}\text { 2020 DairyNZ FVI } \\
\text { for Lower } \\
\text { South Island }\end{array}$ \\
\hline Absolute value & 1.00 & 1.00 & 1.00 & 0.94 \\
Order rankings & 1.00 & 1.00 & 1.00 & 0.93 \\
Star ratings & 1.00 & 0.99 & 0.99 & 0.92 \\
\hline
\end{tabular}

1 Regression coefficient of the values for perennial ryegrass cultivars compared with the change in forage-cultivar DST livestock production-scenario 1.

2 Based on star rating system described by DairyNZ (2020).

4-star rated category of which four of these cultivars were not categorised as 4-star rated using the Scenario 1 DST method.

\section{Discussion}

Results of this study support the hypothesis that use of $\mathrm{S} \& \mathrm{~B}$ economic weightings for the seasonal DM trait would result in different forage evaluation rankings of cultivars compared with using dairy economic weightings. This highlights the importance of having a forage evaluation system developed specifically for the S\&B industry. The differences were typified by the differences in cultivars in each star rating group, and the regression coefficient of rankings of cultivars calculated using the lower South Island DairyNZ FVI being 0.93 when compared with the DST cultivar rankings using Scenario 1. Differences in cultivar rankings can be attributed to the differences in economic weighting for the seasonal DM trait, in the late spring and summer period. For instance, the DairyNZ FVI had economic values of $\$ 0.19 / \mathrm{kg}$ DM and $\$ 0.07 / \mathrm{kg}$ DM in late spring and summer respectively for the lower South Island seasonal DM trait. In contrast, the DST-Scenario 1 had economic weightings of $\$ 0.36$ and $\$ 0.29 / \mathrm{kg}$ DM for late spring and summer, respectively. The main difference in relative seasonal weighting was because the economic values were calculated for a broader range of classes of livestock. Greater diversity in classes of livestock meant there were different economic values for the additional pasture DM at different times of year. A further contributor to this difference in relative weighting of seasonal DM traits in the DST was the use of barley energy costs as an estimate of the opportunity cost of gains in body condition score of the breeding classes of livestock. These classes of livestock were estimated to consume the majority of pasture DM throughout the year. Therefore, the greatest IWF were assigned to the economic values associated with the breeding classes of livestock.

There are advantages to using the equivalent barley energy cost to assess the value of additional DM (through increased body condition score of breeding classes of livestock). One advantage is that it is relatable to farmers, given many farmers know the value of barley supplements. Another advantage is that it overcomes the complexity of assessing the value of body condition score when the flow-on effects (on productivity) from changes in body condition score of breeding livestock may occur in another season or year. This is because the effects on productivity from a change in body condition score can be variable and are likely to be curvilinear (Kenyon et al. 2014). One drawback to the use of equivalent barley energy cost method is that it may not sufficiently account for variation in value of the seasonal DM trait (Ludemann \& Smith 2016). Scenario 2 was, therefore, modelled to assess the effects of reducing the economic weighting of seasonal DM (from changes in the breeding livestock body condition scores) in late spring. This is a time when farmers are unlikely to use barley as a source of feed and late spring pasture supply is generally in excess of demand by livestock. It was, therefore, assumed in Scenario 2 that excess pasture supply in late spring could be used to improve body condition score of breeding livestock classes at a reduced (zero) cost. A comparison between Scenarios 1 and 2 revealed that similar rankings of cultivars (based on the DST Scenario 2) would be maintained even if the contribution of value from extra pasture DM was set to zero from the breeding classes of livestock. Indeed, the relative rankings of the three functional groups of cultivars were similar across scenarios with lateheading diploids generally having greater mean DST values than tetraploids and tetraploids having greater DST than mid-heading diploid cultivars. It must be acknowledged that these results are for a single trait, and inclusion of other traits such as metabolisable energy and persistence may alter these rankings (Ludemann \& Chapman 2019). Consideration should also be given to the greater soil moisture and soil fertility requirements of tetraploid cultivars (Sugiyama 2006), especially in 
a hill-country environment. However, for the seasonal DM production trait, there appears to be stability of the rankings of cultivars to changes in economic weightings of the seasonal DM trait when using the DST method. This is an advantage when generalising results to a broader region in a forage evaluation system.

Analysis of Scenario 3 provides further rationale for the change in livestock production method being deployed at the regional level in a DST. The only difference in assumptions between Scenario 2 and 3 was that the mating date in Scenario 3 was 30 -days later. The same rankings of cultivars $\left(\mathrm{R}^{2}\right.$ of 1.0 for cultivar order rankings) were estimated when Scenarios 2 and 3 were analysed. This result has important implications for the applicability of FVI results to farm systems with different average mating dates if a S\&B farmer were to select their ryegrass cultivars based on a regional-level calculation of DST. Even if a farmer had a different mating date than assumed in the regional DST calculation, the relative rankings of cultivars would remain applicable to that farmer's situation.

The relative stability of forage evaluation systems to changes in trait economic weightings is not surprising. To the author's knowledge no published studies have compared rankings of cultivars when trait economic weightings have been calculated using assumptions for different farming enterprises (e.g. dairy versus $\mathrm{S} \& \mathrm{~B}$ ). However, each year when economic values are updated in the DairyNZ FVI, the rankings of cultivars tend to remain similar (although this effect is confounded by a concomitant inclusion of new trait performance data and new cultivars) (Ludemann 2019; DairyNZ 2020). Furthermore, studies that have assessed the effect of including new traits in the DairyNZ forage evaluation system indicated the rankings of cultivars were generally inelastic to the addition of traits, albeit with some variation by functional groups (Ludemann et al. 2018; Ludemann \& Chapman 2019).

Considering the generalisability of the change in livestock production method described in this study and how relatable it can be to farmers to understand, the method lends itself well to use in calculation of the relative rankings cultivars of perennial ryegrass for the New Zealand S\&B industry at a regional level. Although Scenario 1 exhibited some of the disadvantages expected when part of the economic weighting is based on equivalent barley costs (i.e. lack of inter-annual variability in economic values), Scenario 2 provided a method that overcame this drawback. Scenario 2, therefore, offers a feasible method for calculating the relative economic value of cultivars of perennial ryegrass based on the seasonal DM trait alone. However, before a decision is made as to what method of calculating the EV of seasonal DM traits is best for the S\&B industry, it is important to first apply the method developed in this study to a wider range of Farm Classes. It is also advisable to compare these results with results calculated using alternative methods of calculation. Alternatives could include the use of the simpler replacement cost method (Lewis et al. 2013; Ludemann \& Smith 2016) and/or the use of surveys of experts through discrete choice surveys (Smith \& Fennessy 2014). The latter of these methods could also provide a framework for building consensus over the relative weightings of forage traits that are difficult to measure, or that are weighted by non-economic values (eg. environmental values).

\section{Conclusions}

Development of an independent S\&B forage-cultivar DST could provide substantial benefits to New Zealand S\&B farmers. This would come through improved cultivar selection at the farm level and better guidance for plant breeders as to which traits to focus on to provide the best on-farm return. This study took a first step toward development of a S\&B forage value index in that it assessed one method of calculating forage trait economic weightings and applied them to the DairyNZ FVI system. The change in livestock production method was applied to the Otago/Southland Breeding Finishing Farm Class in this study for analysis and showed differences in rankings of cultivars when compared with the DairyNZ FVI. The change in livestock production method, therefore, offers an option for calculating the economic value of traits for evaluation of perennial ryegrass cultivars that are more applicable to S\&B farmers. However, before a decision is made as to the suitability of this method for the New Zealand S\&B industry, it should be applied to a wider range of S\&B Farm Classes. While far from complete as a system, the present study shows the potential for a forage evaluation system to be developed for a range of S\&B farms similar to the DairyNZ FVI.

\section{ACKNOWLEDGEMENTS}

This project (Project BLNZT1701) is part of the Hill Country Futures Programme. Funding for this project was gratefully received from Beef and Lamb New Zealand, the Ministry of Business, Innovation and Employment (MBIE), Seed Force New Zealand and PGG Wrightson Seeds. The author is grateful for access to data and feedback from the New Zealand Plant Breeding and Research Association and DairyNZ for use of the DairyNZ FVI framework.

\section{REFERENCES}

Beef +Lamb NZ. 2019. Economic service sheep and beeffarm survey. Retrieved 11 December 2019 from: https://beeflambnz.com/data-tools/sheep-beef-farmsurvey 
Behrendt K, Cacho O, Scott JM, Jones R. 2013. Optimising pasture and grazing management decisions on the Cicerone Project farmlets over variable time horizons. Animal Production Science 53: 796-805. https://doi.org/10.1071/AN11174

Byrne TJ, Ludemann CI, Amer PR, Young MJ. 2012. Broadening breeding objectives for maternal and terminal sheep. Livestock Science 144: 20-36. https:// doi.org/10.1016/j.livsci.2011.10.010

Chapman DF, Bryant JR, Olayemi ME, Edwards GR, Thorrold BS, McMillan WH, Kerr GA, Judson G, Cookson T, Moorhead A, Norriss M. 2017. An economically based evaluation index for perennial and short-term ryegrasses in New Zealand dairy farm systems. Grass and Forage Science 72: 1-21. https:// doi.org/10.1111/gfs.12213

CSIRO. 2007. Nutrient Requirements of Domesticated Ruminants. Melbourne, Australia: CSIRO Publishing, $295 \mathrm{p}$.

DairyNZ. 2017. Inside Dairy: Forage index guiding choices. https://www.dairynz.co.nz/media/5694869/ Inside_Dairy_February_2017_WEB.pdf.

DairyNZ. 2020. The DairyNZ FVI Handbook 2020 edition. Newstead, New Zealand: DairyNZ, 50 p.

Hardin LS, Johnson GL. 1955. Economics of forage evaluation. Journal of Farm Economics 37: 14571459. https://doi.org/10.2307/1234057

Kenyon PR, Maloney SK, Blache D. 2014. Review of sheep body condition score in relation to production characteristics. New Zealand Journal of Agricultural Research 57: 38-64. https://doi.org/10.1080/002882 33.2013 .857698

Leddin CM, Jacobs JL, Smith KF, Giri K, Malcolm B, Ho CKM. 2018. Development of a system to rank perennial ryegrass cultivars according to their economic value to dairy farm businesses in southeastern Australia. Animal Production Science 58: 1552-1558. https://doi.org/10.1071/AN17815

Lewis CD, Malcolm B, Jacobs JL, Spangenberg GC, Smith KF. 2013. A method to estimate the potential net benefits of trait improvements in pasture species: Transgenic white clover for livestock grazing systems. Australian Farm Business Management Journal 10: 30-45. https://doi.org/10.1016/j. agsy.2019.102729

Lewis CD, Smith KF, Jacobs JL, Ho CKM, Leddin CM, Malcolm B. 2020. Using a two-price market value method to value extra pasture DM in different seasons. Agricultural Systems 178: 102729.

Ludemann CI, Cullen BR, Malcolm B, Smith K. 2013. Economic values of changes in energy concentration of pasture in contrasting temperate dairy regions in Australia. Australian Farm Business Management Journal 10: 1-15.
Ludemann CI, Smith KF. 2016. A comparison of methods to assess the likely on-farm value for meat production systems of pasture traits and genetic gain through plant breeding using phalaris (Phalaris aquatica L.) as an example. Grass and Forage Science 71: 66-78. https://doi.org/10.1111/gfs.12164

Ludemann CI, Wims CM, Chapman DF. 2018. Changes in rankings of cultivar/endophyte combinations in the DairyNZ Forage Value Index when a metabolisable energy trait is included. Journal of New Zealand Grasslands 80: 215-218. https://doi.org/10.33584/ jnzg.2018.80.314.

Ludemann CI, Chapman DF. 2019. Inclusion of persistence in the DairyNZ Forage Value Index. Journal of New Zealand Grasslands 81: 203-208. https://doi.org/10.33584/jnzg.2019.81.375

Ludemann CI. 2019. The DairyNZ FVI Handbook 2019 edition. Newstead, Waikato, NZ: DairyNZ Ltd, 51 p.

McEvoy M, O'Donovan M, Shalloo L. 2011. Development and application of an economic ranking index for perennial ryegrass cultivars. Journal of Dairy Science 94: 1627-1639. https://doi. org/10.3168/jds.2010-3322

O'Donovan M, McHugh N, McEvoy M, Grogan D, Shalloo L. 2016. Combining seasonal yield, silage dry matter yield, quality and persistency in an economic index to assist perennial ryegrass variety selection. Journal of Agricultural Science 155: 556-568. https:// doi.org/10.1017/S0021859616000587

Rayner A. 2007. Using oats as an alternative grain in opportunity feedlot rations. Glen Innes, NSW: DPI, 4 p. http://www.dpi.nsw.gov.au/_data/assets/ pdf_file/0017/101339/Using-oats-as-an-alternativegrain-in-opportunity-feedlot-rations.pdf

Smith KF, Fennessy PF. 2011. The use of conjoint analysis to determine the relative importance of specific traits as selection criteria for the improvement of perennial pasture species in Australia. Crop and Pasture Science 62: 355-365. https://doi.org/10.1071/CP10320

Smith KF, Fennessy PF. 2014. Utilizing conjoint analysis to develop breeding objectives for the improvement of pasture species for contrasting environments when the relative values of individual traits are difficult to assess Sustainable Agriculture Research 3: 44-55 https://doi.org/10.5539/sar.v3n2p44

Sugiyama S-i. 2006. Responses of shoot growth and survival to water stress gradient in diploid and tetraploid populations of Lolium multiflorum and L. perenne. Grassland Science 52: 155-160. https:// doi.org/10.1111/j.1744-697X.2006.00062.x

Upsdell M, Cosgrove GP, Ganesh S, Koolard J, Pacheco D, Crush J. 2017. Metabolisable energy and crude protein concentrations in grazed pastures in New Zealand. Wellington: New Zealand Government, 82 p. https://www.mpi.govt.nz/dmsdocument/32869/send 
Wims CM, Ludemann CI, Phillips H, Chapman DF. 2017. The economic value to dairy systems of genetic gains in the nutritive value of perennial ryegrass in grass-clover pastures. Animal Production Science 57: 1357-1365. https://doi.org/10.1071/AN16487 